\title{
Effect of reclamation on the structure of silty-clay soils irrigated with saline-sodic waters**
}

\author{
Giovanna Cucci ${ }^{*}$, Giovanni Lacolla ${ }^{1}$, Marcello Pagliai ${ }^{2}$, and Nadia Vignozzi ${ }^{2}$ \\ ${ }^{1}$ Department of Agricultural and Environmental Science, University of Bari “A. Moro". Via Amendola, 165/A, 70125 Bari, Italy \\ ${ }^{2}$ Agricultural Research Council Agrobiology and Pedology Research Centre CRA-ABP., Piazza D’Azeglio 30, \\ 50121, Florence, Italy
}

Received June 13, 2014; accepted November 26, 2014

\begin{abstract}
A b s t r a c t. The objective of the work was to evaluate, by using the micromorphometric method, the effects of reclamation on porosity of two different clay loam soils irrigated with saline-sodic waters. Soil samples of the Ap horizon were put in cylindrical containers and irrigated with 9 types of saline-sodic waters ( 3 levels of salinity combined with 3 levels of sodicity). After a 4-year period, correction treatments were initiated by addition of calcium sulphate and leaching until electrical conductivity and sodium absorption ratio values of the drainage water matched $3 \mathrm{dS} \mathrm{m}^{-1}$ and 9, respectively. After 2 years of correction treatments, undisturbed soil samples were taken from the surface layer and soil thin sections for porosity measurements. Both soils did not show critical macroporosity values $(>10 \%$, below this threshold a soil is classified as compact). Nevertheless, the soils exhibited a different behaviour: total porosity of the Pachic Haploxeroll soil was not affected by difference in water salinity and alkalinity; on the contrary, the Udertic Ustochrept soil showed a lower porosity associated with higher salt concentration in the irrigation waters. This may be due to the different iron and aluminium sesquioxides content and, as a consequence, a different effect on soil aggregate stability.

K e y w o r d s: soil structure, soil porosity, salinity, image analysis, bulk density
\end{abstract}

\section{INTRODUCTION}

Soil salinization is a serious eco-environmental problem in the arid and semiarid regions of the world that is increasingly threatening the sustainability of irrigated farming (Chhabra, 2005). The use of irrigation water with high salt and sodium levels may cause harmful effects both on the existing crops and on the physical soil properties, notably

\footnotetext{
*Corresponding author e-mail: giovanna.cucci@uniba.it **This work was part of the co-operative research programme No. 9807038430 co-financed by the Ministry for University and Scientific and Technological Research (Italy), and the University of Bari, 2007.
}

on soil structure, so assessing the potential risks associated with it would be recommended before deciding whether you need to apply this practice.

To better evaluate the effect of salinity on the soil it is necessary to know the salt composition, in particular sodium concentration. Actually, sodium has the opposite effect to salinity on soils. While a high salt concentration may usually increase flocculation, saturation with sodium causes its dispersion. The soil type (texture, mineralogy and clay composition, content of organic matter and inorganic binders), the irrigation techniques and rainfall also influence the flocculation and dispersion of colloidal particles (Ayers and Westcot, 1985; Ladeiro, 2012; Qadir and Oster, 2004).

In saline soils and under the typical semi-arid conditions of the Mediterranean environments, irrigation is often applied using unconventional water. During the irrigation season, large amounts of soluble salts and low quantities of exchangeable sodium favour the state of flocculation of clay particles, thus ensuring a good structural status and free circulation of air and water along the soil profile. However, the first rainfall triggers, especially in top horizons, leaching processes that cause solute transportation towards the lower part of the profile or their final disposal. Moreover, since these structural elements are highly unstable towards the weathering action of water, they tend to get dispersed causing the clogging of large pores and the change to massive forms of structure, thus reducing the hydraulic conductivity and the soil ability to drain excess water.

(C) 2015 Institute of Agrophysics, Polish Academy of Sciences 
Hence, in these soils the structure is subject to a definite seasonal dynamics, changing from optimal granular or angular and sub-angular polyhedral forms to massive forms. There are also soils with a high sodium content in the soil solution. The subsequent formation of sodic clays and the destruction of aggregates originates, in natric horizons, coarse and, in more severe cases, even massive column structures (Abdelgawad et al., 2004).

In particular, the harmful effects of sodium in clay soils vary according to the clay mineral composition (Saskatchewan Water Corporation, 1987); sodium excess reduces in particular the permeability in soils with prevailing montmorillonite clays as compared to soils containing illite-vermiculite and kaolinite, and major problems occur when $\mathrm{Na}^{+}$ excess is associated with a low salt concentration. Hence, $\mathrm{Na}^{+}$induces deflocculation, favouring - in the long-term - an increase in soil bulk density and a higher micropore/ macropore volume ratio.

Many research works have proved the beneficial effects of calcium sulphate application on the physicochemical properties of sodic-saline soils, including a rise in permeability and leaching (Ilyas et al., 1997), an increase in soil flocculation and macroporosity (Greene et al., 1988), and a reduction of surface crusting (Gal et al., 1984).

Over the last fifteen years new methods have been developed for the control and monitoring of saline soils. These methods have been grouped as hydraulic, physical, chemical and biological. The latter include different techniques such as the phyto-desalination due to four main factors:

$-\mathrm{CO}_{2}$ partial pressure in the root-zone,

- release of protons from roots (in the case of $\mathrm{N}_{2}$ fixing plants),

- improvement of porosity and soil structure with pore size increase subsequent to root expansion;

- removal of soil-contained sodium through the abstraction of vegetation (Sakai et al., 2012).

Many authors encourage the use of hyper-accumulating halophytic plants for soil desalinization (Quadir and Oster, 2004).

The growing of crops appropriate to the local conditions, the supply of organic matter, the proper use of agricultural practices, the development of irrigation in rice-fields, the growing of Melilotus officinalis L. and other salt-tolerant crops, are all useful methods to improve saline soils (Bian et al., 2012; Sakai, 2012; Zao et al., 2012).

In Songnen plain (China), within the Daan irrigation scheme, a study was also performed on the effect of freezing and thawing on soil salinization (Zhang and Wang, 2000).

The knowledge of the soil-water relationship and of the physicochemical and saline features in sodic-saline areas is essential to support governmental agencies for the development of sustainable agriculture policies and for land protection against degradation. As for the physical soil properties, the quality of the structural status may be evaluated through the quantification and characterization of the pore system, the bulk density and the assessment of the stability index of structural aggregates. The purpose of this paper is to assess the effects of reclamation on the structural quality of two different soils irrigated with sodic-saline water.

\section{MATERIALS AND METHODS}

The study was conducted on two silty-clay textured soils, ie classified as Udertic Ustochrept, Montefalcone series (Bologna G-OM) and Pachic Haploxeroll, Cutino series (Locorotondo R-OM $)$ (Soil Survey Staff, 2006). The characteristics of the two soil types are reported in Table 1.

The soil called Bologna, characterized by a gray colour (G-), has a predominance of vermiculite and illite, small quantities of iron and aluminium sesquioxides and a lower content of organic matter $\left(\mathrm{OM}_{1}\right)$ than the soil called Locorotondo; the latter, red coloured (R-), is characterized by a predominance of illite and kaolinite, large amounts of iron and aluminium sesquioxides and a higher organic matter content $\left(\mathrm{OM}_{\mathrm{h}}\right)$ as compared to Bologna soil. The soil samples, taken from the Ap horizon of each soil, were placed in cylindrical pots $(0.40 \mathrm{~m}$ in diameter and $0.60 \mathrm{~m}$ in height, equipped with a bottom valve for the discharge of drainage water, placed under a shed to prevent the leaching action of rainfall) and irrigated with 9 types of sodic-saline water: 3 salinity levels $\left(10-32-64 \mathrm{mmol} \mathrm{l}^{-1}\right)$ combined with 3 sodium absorption ratio levels $(\mathrm{SAR}=5-15-45)$ and using 20\% leaching fraction. The 9 types of water were obtained by dissolving adequate amounts of $\mathrm{NaCl}$ and $\mathrm{CaCl}_{2}$ in de-ionized water. The research was conducted following the split-plot experimental design with three replicates.

The experiment was carried on for four years after which the soils were analysed for saturation extract electrical conductivity (ECe), $\mathrm{pH}$ and exchangeable sodium percentage (ESP), following the official methods (Violante, 2000). Moreover, soil bulk density was measured by the core method (Ø $7 \mathrm{~cm}$ and h $7.5 \mathrm{~cm}$ ) (Blake and Hartge, 1986) taking undisturbed samples from the soil top layer $(0-10 \mathrm{~cm})$ in three replicates for each pot.

Afterwards, different soil conditioning treatments were selected, ie application of calcium sulphate, growing of a salt-tolerant crop followed by a legume, application of leaching water. The 2 soils, grown with a cereal (barley) followed by legume (Borlotti bean), were irrigated with fresh water $\left(\mathrm{EC}_{\mathrm{w}}=0.5 \mathrm{dS} \mathrm{m}^{-1}\right.$ and $\left.\mathrm{SAR}=0.45\right)$ whenever $30 \%$ of the maximum available moisture was lost by evapotranspiration in the soil contained in pots. Soil conditioning treatments involved the application of calcium sulphate to the soils with ESP $>6 \%$ and the application of leaching fractions equal to $20 \%$ of the watering volume for more saline soils and proportionately lower fractions for less saline soils, until the electrical conductivity and the SAR of drainage water reached 3 and $9 \mathrm{dS} \mathrm{m}^{-1}$, respectively. 
T a b l e 1. Main chemical and hydrologic properties of the two soil types before the start the experiment

\begin{tabular}{|c|c|c|c|}
\hline \multirow{2}{*}{ Parameter } & \multirow{2}{*}{ Unit } & \multicolumn{2}{|c|}{ Soil type } \\
\hline & & Udertic Ustochrept & Pachic Haploxeroll \\
\hline \multicolumn{4}{|c|}{ Particle-size analysis (mm) } \\
\hline Total sand (2-0.02) & & 30.27 & 20.94 \\
\hline Silt (0.02-0.002) & $\left(\mathrm{g} 100 \mathrm{~g}^{-1}\right)$ & 33.10 & 44.00 \\
\hline Clay $(<0.002)$ & & 36.63 & 35.06 \\
\hline \multicolumn{4}{|c|}{ Chemical properties } \\
\hline Total nitrogen ( Kjeldahl method) & $\left(\mathrm{g} 100 \mathrm{~g}^{-1}\right)$ & 0.79 & 1.65 \\
\hline Available phosphorus (Olsen method) & $\left(\mathrm{mg} \mathrm{kg}^{-1}\right)$ & 31.50 & 52.50 \\
\hline Exchangeable potassium $\left(\mathrm{BaCl}_{2}\right.$ method $)$ & $\left(\mathrm{mg} \mathrm{kg}^{-1}\right)$ & 160.00 & 352.00 \\
\hline Organic matter (Walkley Black method) & $\left(\mathrm{g} 100 \mathrm{~g}^{-1}\right)$ & 1.21 & 3.13 \\
\hline Total limestone (met. Calc. Dietrich-Fruhling) & $\left(\mathrm{g} 100 \mathrm{~g}^{-1}\right)$ & 0.47 & 2.58 \\
\hline Active limestone & $\left(\mathrm{g} 100 \mathrm{~g}^{-1}\right)$ & 0.05 & 1.40 \\
\hline $\mathrm{ECe}$ & $\left(\mathrm{dS} \mathrm{m} \mathrm{m}^{-1}\right)$ & 0.65 & 0.68 \\
\hline ESP & $(\%)$ & 0.70 & 0.80 \\
\hline $\mathrm{pH}\left(\mathrm{pH}\right.$ in $\left.\mathrm{H}_{2} \mathrm{O}\right)$ & & 7.09 & 7.18 \\
\hline $\mathrm{CEC}\left(\mathrm{BaCl}_{2}\right.$ method $)$ & (meq $\left.100 \mathrm{~g}^{-1}\right)$ & 34.00 & 38.00 \\
\hline \multicolumn{4}{|c|}{ Hydrologic properties } \\
\hline Field capacity (field determ.) & (g $100 \mathrm{~g}^{-1}$ d.m.) & 34.50 & 35.80 \\
\hline Wilting point (-1.5 MPa) & (g $100 \mathrm{~g}^{-1}$ d.m.) & 14.70 & 18.40 \\
\hline Bulk density & $\left(\mathrm{kg} \mathrm{dm}^{-3}\right)$ & 1.22 & 1.18 \\
\hline
\end{tabular}

$\mathrm{BaCl}_{2}$ - barium chloride, ECe - saturation extract electrical conductivity, ESP - exchangeable sodium percentage, CEC - cation exchange capacity.

After two-year soil conditioning treatments, disturbed and undisturbed soil samples were taken and used to determine macroporosity, bulk density and the structural/ aggregate stability index.

Soil macroporosity was evaluated by the micromorphometric method (Pagliai et al., 2004). This method allows the quantification of soil macroporosity with regard to pore shape, pore size distribution, irregularity, orientation, continuity, etc. on thin sections. Vertically oriented thin sections were obtained from undisturbed soil samples taken from the top layer $(0-10 \mathrm{~cm})$ (two samples for each pot - six replicates for each treatment). The samples were dried by acetone replacement (Miedema et al., 1974) and impregnated under vacuum with a polyester resin. The impregnated blocks were cut into $6 \mathrm{~cm}$ high $\mathrm{x} 7 \mathrm{~cm}$ wide $\mathrm{x}$
$30 \mu \mathrm{m}$ thick vertically oriented thin sections. Thin sections were examined by image analyzer, using the Image-Pro Plus software produced by 'Media Cybernetics' (Silver Spring MD, USA). Total porosity and pore distribution were measured according to pore shape and size, the instrument being set up to measure pores larger than $50 \mu \mathrm{m}$. Pore shape was expressed by a shape factor [perimeter ${ }^{2}$ $\left.(4 \pi \text { area })^{-1}\right]$ so that pores could be divided into regular (more or less rounded, shape factor 1-2), irregular (shape factor $2-5$ ), and elongated (shape factor $>5$ ). These classes correspond approximately to those used by Bouma et al. (1977). Pores of each shape group can be further subdivided into size classes (50-100, 100-200, 200-300, 300-400, 400-500, $500-1000,>1000 \mu \mathrm{m})$ according to either their equivalent pore diameter (regular and irregular pores), or their width 
(elongated pores) (Pagliai et al., 1984). Thin sections were also examined using a Zeiss ' $R$ POL' microscope at $25 \mathrm{x}$ magnification to observe soil structure.

Soil bulk density was measured according to the procedure described previously.

On composite soil samples taken along the whole profile, the structure stability was assessed using the wet sieving method with mechanic vertical oscillation with or without alcohol pre-treatment. (Hénin et al., 1969; Kemper and Rosenau, 1986). The apparatus was equipped with vertical supports to which 6 sieves with $0.2 \mathrm{~mm}$ mesh size were fixed. The sieves were subjected to vertical oscillation with a stroke of $30 \mathrm{~mm}$ and a frequency of 30 oscillations $\mathrm{min}^{-1}$ for $30 \mathrm{~min}$. For each soil sample, $10 \mathrm{~g}$ of air dried aggregates in the range of 1-2 mm (air dried or pre-wetted with ethanol) was submerged in $300 \mathrm{~cm}^{3}$ of deionized water for $30 \mathrm{~min}$, then transferred to sieves previously dipped in deionized water and subjected to a vertical oscillating movement. The remaining aggregates were oven dried at $105^{\circ} \mathrm{C}$ and subjected to a dispersion treatment $\left(40 \mathrm{~g} \mathrm{l}^{-1}\right.$ sodium hexametaphosphate and $10 \mathrm{~g} \mathrm{l}^{-1}$ sodium carbonate) for coarse sand determination.

The water stability index (WSI) was calculated as $(\mathrm{B}-\mathrm{C}) /((\mathrm{A} \times \mathrm{k})-\mathrm{C}) \times 100$, where $\mathrm{A}$ is the mass of air-dried soil aggregates, $\mathrm{B}$ is the oven-dry mass of aggregates remaining in the sieve, $\mathrm{C}$ is the mass of sand fraction and $\mathrm{k}$ is the correction factor for soil moisture content $(\mathrm{k}=$ mass of oven-dry aggregates divided by the mass of air-dry aggregates). Each determination was made at least in triplicate (Pagliai et al., 1997).

The tested and calculated parameters were subjected to the variance analysis using the SAS software, and the means were evaluated by Duncan test.

\section{RESULTS AND DISCUSSION}

The results of chemical analyzes conducted after a fouryear period of irrigation with sodic-saline water, applied in some cases with $\mathrm{ECW}$ and SAR falling within the quality class with severe limitations for potential damage to the structure, show an increase in salt concentration $\left(>4 \mathrm{dS} \mathrm{m}^{-1}\right)$ and soil sodium (Table 2). Therefore, the soils irrigated with water of higher salt concentration and higher sodium level (64 $\mathrm{mmol} \mathrm{l}^{-1}$ and SAR 45) showed saturation extract electrical conductivity values (ECe) equal to 15.64 and 20.96 $\mathrm{dS} \mathrm{m} \mathrm{m}^{-1}$ and ESP values of 13.86 and $12.01 \%$, respectively, for $\mathrm{G}-\mathrm{OM}_{1}$ and $\mathrm{R}-\mathrm{OM}_{\mathrm{h}}$ (Table 2). However, the ESP values were always lower than 15 . For this reason, in accordance with the U.S. Salinity Laboratory Staff (1954), the soils under study cannot be classified as sodic-saline.

The treatments with calcium sulphate, commonly used to reclaim sodic and sodic-saline soils, were applied because the results obtained by Cavazza et al. (2002) on soil structure stability have pointed out that an increase in sodium percentage results in a gradual reduction of aggregate stabi- lity. In particular, R-OM ${ }_{h}$, characterized by a higher intrinsic structural stability than $\mathrm{G}_{-} \mathrm{OM}_{1}$, keeps constant stability values only until ESP values below 5, then they quickly decrease.

After two years of reclamation (by chemical, biological, hydraulic and physical methods), in both soils, macroporosity values are not critical, they are in the range of $10-25 \%$ and, according to the micromorphometric method (Pagliai, 1988), correspond to moderately porous soil. However, the

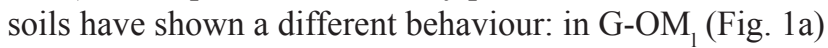
porosity is lower in the treatments irrigated with water of higher salt concentration, whereas $\mathrm{R}-\mathrm{OM}_{\mathrm{h}}$ has not shown any difference in terms of total porosity with the increase in salinity and alkalinity (Fig.1b).

Pore shape and size distribution revealed that the decrease of porosity in $\mathrm{G}_{-} \mathrm{OM}_{1}$ following the increase of salinity of irrigation water was mainly due to the decrease of the proportion of elongated continuous pore (Fig. 2), while in $\mathrm{R}-\mathrm{OM}_{\mathrm{h}}$, as was the case of total macroporosity, the pore shape and size distribution did not show significant differences.

Micromorphological observations showed that the higher value of total macroporosity, particularly elongated pores, in $\mathrm{G}-\mathrm{OM}_{1}$ irrigated with low salinity water produced a good subangular blocky structure (Fig. 2), while the decrease of porosity in this soil irrigated with high salinity water produced a more compact soil structure. Following the same trend of soil macroporosity, the R-OM $\mathrm{M}_{\mathrm{h}}$ showed the same rather compact subangular blocky structure independent of the level of salinity in the irrigation water. Russo (2013) has also reported variations in the pore distribution during the interaction between matrix and soil solution as a function of the mineralogical composition, in particular in the presence of montmorillonite.

The soil variations after two years of reclamation treatments are confirmed by the significant reductions in soil bulk density that are more accentuated in $\mathrm{R}-\mathrm{OM}_{\mathrm{h}}$ soil, probably due to its particular mineralogical composition. The bulk density of the 2 soils that after the four-year irrigation with sodic-saline water showed mean values of 1.26 $\mathrm{kg} \mathrm{dm}^{-3}\left(\mathrm{G}-\mathrm{OM}_{\mathrm{H}}\right)$ and $1.23 \mathrm{~kg} \mathrm{dm}^{-3}\left(\mathrm{R}-\mathrm{OM}_{\mathrm{h}}\right)$ decreased with reclamation treatments to a different extent for the two soils (1.7 and 3.3\%, respectively for the $\mathrm{G}-\mathrm{OM}_{1}$ and $\mathrm{R}-\mathrm{OM}_{\mathrm{h}}$ soils) (Table 2, Fig. 4). Therefore, the soil R-OM ing a predominance of illite and kaolinite, large amounts of iron and aluminium sesquioxides and a double organic matter content, re-established its physicochemical properties following the reclamation treatments more quickly compared to the soil $\mathrm{G}_{-} \mathrm{OM}_{1}$, characterized by a predominance of vermiculite and illite and small quantities of iron and aluminium sesquioxides. The reduction of soil bulk density has an effect on water and air contents in soil and it also significantly influences permeability, drainage, and root penetration and growth. 
T a b l e 2. Electrical conductivity (ECe), $\mathrm{pH}$, exchangeable sodium percentage (ESP) of the soil saturation extract and bulk density (Bd) before conditioning

\begin{tabular}{|c|c|c|c|c|c|}
\hline $\begin{array}{l}\text { Salt concentration } \\
\quad\left(\mathrm{mmol} \mathrm{l}^{-1}\right)\end{array}$ & SAR & $\begin{array}{c}\mathrm{ECe} \\
\left(\mathrm{dS} \mathrm{m}^{-1}\right)\end{array}$ & $\begin{array}{c}\mathrm{pH} \\
\left(\mathrm{H}_{2} \mathrm{O}\right)\end{array}$ & $\begin{array}{l}\text { ESP } \\
(\%)\end{array}$ & $\begin{array}{c}\mathrm{Bd} \\
\left(\mathrm{Mg} \mathrm{m}^{-3}\right)\end{array}$ \\
\hline \multicolumn{6}{|c|}{ Udertic Ustochrept } \\
\hline & 5 & 6.01 & 7.69 & 3.06 & 1.23 \\
\hline \multirow[t]{3}{*}{10} & 15 & 5.48 & 7.77 & 3.12 & 1.25 \\
\hline & 45 & 4.91 & 7.87 & 3.29 & 1.27 \\
\hline & 5 & 12.00 & 7.72 & 4.65 & 1.24 \\
\hline \multirow[t]{3}{*}{32} & 15 & 9.32 & 7.82 & 7.21 & 1.26 \\
\hline & 45 & 8.11 & 7.87 & 6.98 & 1.28 \\
\hline & 5 & 21.05 & 7.71 & 8.61 & 1.25 \\
\hline \multirow[t]{2}{*}{64} & 15 & 18.00 & 7.77 & 12.58 & 1.27 \\
\hline & 45 & 15.64 & 7.95 & 13.86 & 1.29 \\
\hline \multicolumn{6}{|c|}{ Pachic Haploxeroll } \\
\hline & 5 & 7.55 & 7.67 & 2.26 & 1.19 \\
\hline \multirow[t]{3}{*}{10} & 15 & 6.31 & 7.73 & 2.58 & 1.23 \\
\hline & 45 & 4.80 & 7.78 & 2.66 & 1.23 \\
\hline & 5 & 15.34 & 7.65 & 4.63 & 1.21 \\
\hline \multirow[t]{3}{*}{32} & 15 & 11.85 & 7.79 & 4.93 & 1.24 \\
\hline & 45 & 9.80 & 7.89 & 8.77 & 1.24 \\
\hline & 5 & 24.15 & 7.76 & 8.37 & 1.22 \\
\hline \multirow[t]{2}{*}{64} & 15 & 21.80 & 7.83 & 11.44 & 1.25 \\
\hline & 45 & 20.96 & 7.94 & 12.01 & 1.26 \\
\hline
\end{tabular}

SAR - sodium absorption ratio.

A similar trend was observed for the soil structural stability index which, from values of 29.3 and $38.3 \%$, after the four-year irrigation with sodic-saline water (Cucci and Lacolla, 2013) increased on average after reclamation by 9.8 and $14.1 \%$, respectively, for the $\mathrm{G}-\mathrm{OM}_{1}$ and $\mathrm{R}-\mathrm{OM}_{\mathrm{h}}$, without any significant effect of the variation of sanility and alcalinity (Fig. 5). Illite and kaolinite largely contribute to stabilising soil structure, notably in soils rich in sesquioxides (Cavazza et al., 2002). The structural/aggregate stability index increased on average by over $16 \%$, shifting from the soils previously irrigated with water with salt concentration of $64 \mathrm{mmol} \mathrm{l}^{-1}$ to those irrigated with water of $10 \mathrm{mmol} \mathrm{l}^{-1}$ (Fig. 6). The low structural stability of non-pretreated samples was always associated with an increased stability after alcohol pretreatment (Fig. 6), the first result reflects the soil surface status (pouring rain effect), whereas the other expresses better its effect below the soil surface (Cavazza et al., 2002; Cucci and Lacolla, 2013).
The available data enable to formulate some considerations on the different behaviours of these two soils. More specifically, in $\mathrm{R}-\mathrm{OM}_{h}$, rich in organic matter $(3.13 \%)$, the presence of iron and aluminium sesquioxides plays a major role, thus confirming that the various forms of $\mathrm{Al}$ and $\mathrm{Fe}$ in the soil favour flocculation and reduce 'swelling' and dispersion mechanisms of clay minerals responsible, under sodic conditions, for modifications in the pore system and consequently in the hydraulic conductivity values (Goldberg and Glaubig, 1987; Shainberg and Levy, 1992). Further studies are needed to account for the behaviour of $\mathrm{G}-\mathrm{OM}_{1}$, a possible interpretation is to recognize the flocculating effect of high salt concentrations on clays, but also the instability of these structural crumbs especially when the soil is subjected to leaching. The higher leaching applications in the $\mathrm{G}-\mathrm{OM}_{1}$ treatments with higher salt concentrations might have caused a quicker structure degradation as compared to less leached treatments with lower salt concentrations. 
a

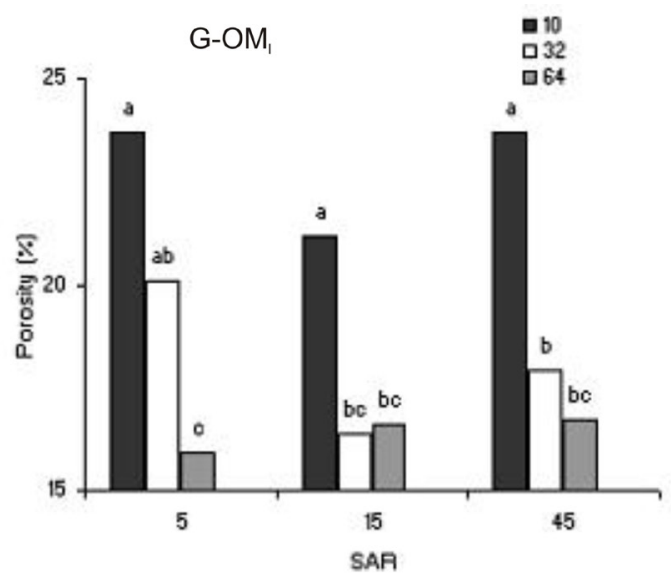

b

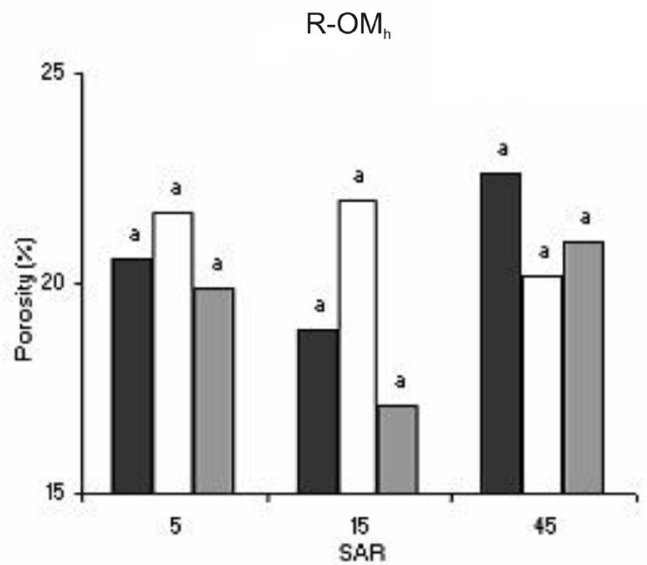

Fig. 1. Total macroporosity, expressed as percent area of pores $>50 \mu \mathrm{m}$ in: a - Udertic Ustochrept soil (G-OM), and b - Pachic Haploxeroll soil $\left(\mathrm{R}-\mathrm{OM}_{\mathrm{h}}\right)$. For each effect considered, the values followed by the same letter are not significantly different, according to the Duncan test at $\mathrm{p} \leq 0.05$.

G-OM, SAR 5
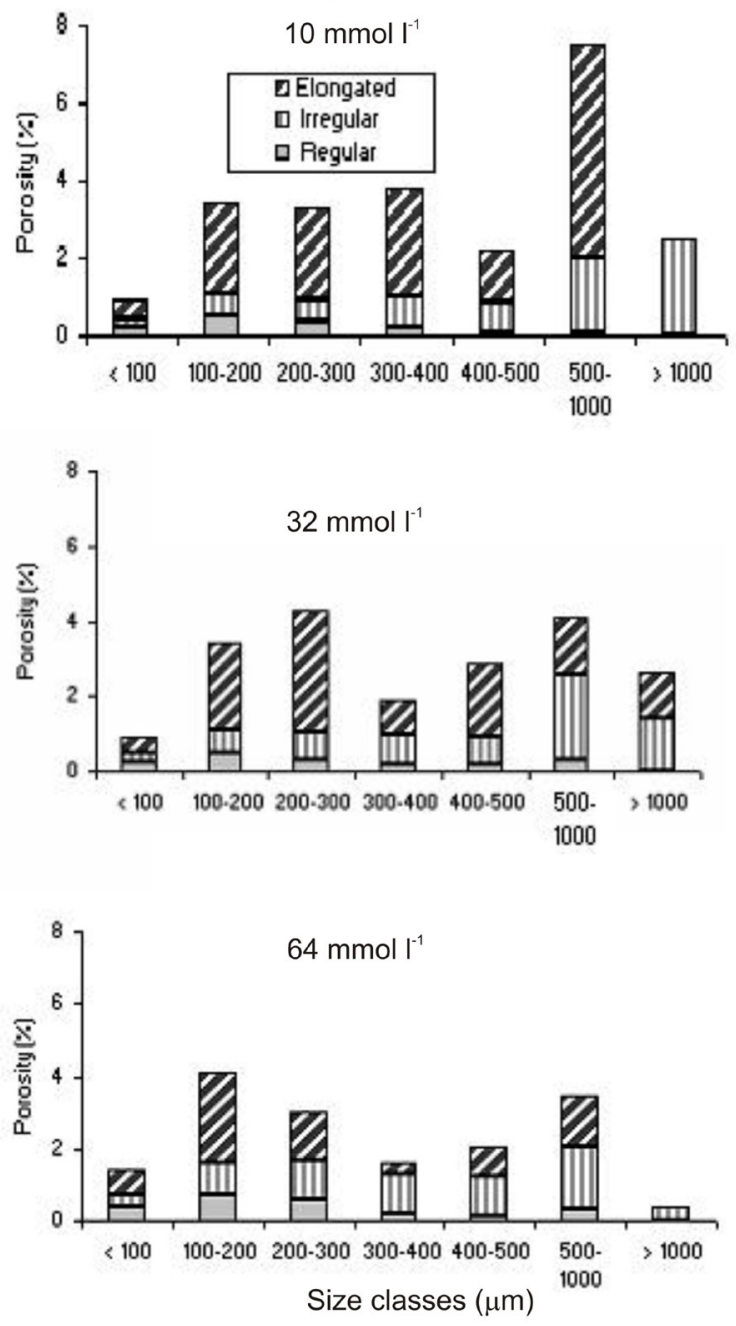

R-OM $\mathrm{M}_{\mathrm{h}}$ SAR 45
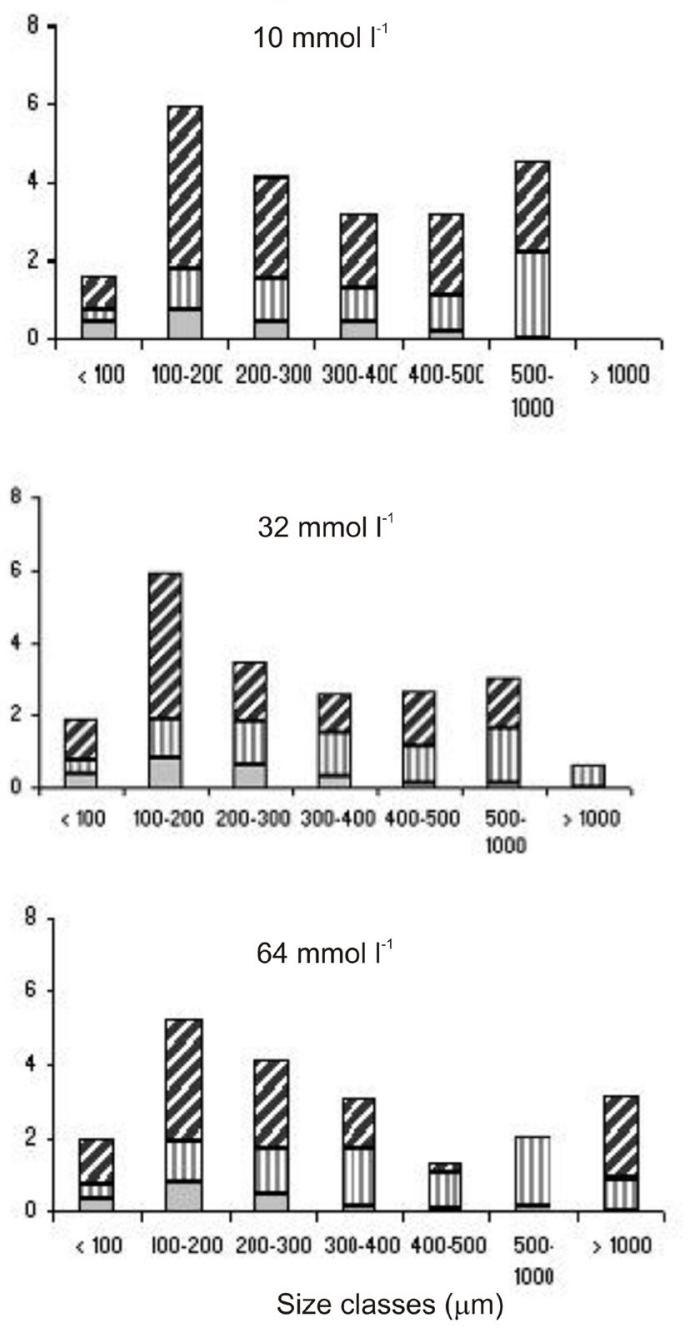

Fig. 2. Pore size distribution, expressed as equivalent pore diameter, for regular and irregular pores and width for elongated pores as related to the soil type (Udertic Ustochrept - G-OM and Pachic Haploxeroll - R-OM $\mathrm{M}_{\mathrm{h}}$ ), salt concentration and SAR (sodium absorption ratio) of irrigation water after two years of reclamation. 

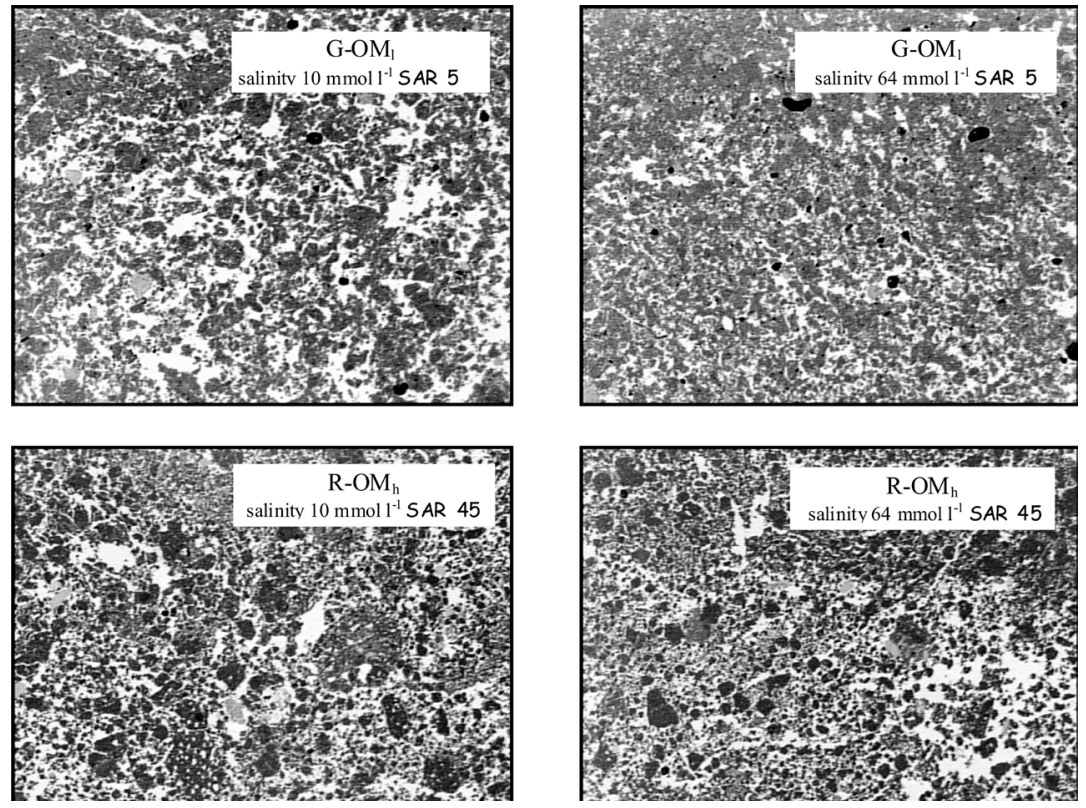

Fig. 3. Macrophotographs of vertically oriented thin sections prepared from undisturbed samples from the two studied soils. In Udertic Ustochrept $(\mathrm{G}-\mathrm{OM})$ there is the effect of salt concentration also at the lowest SAR level, whereas in Pachic Haploxeroll (R-OM $\left.)_{h}\right)$ the porosity does not change with different salt concentrations, even when using water with higher SAR levels.
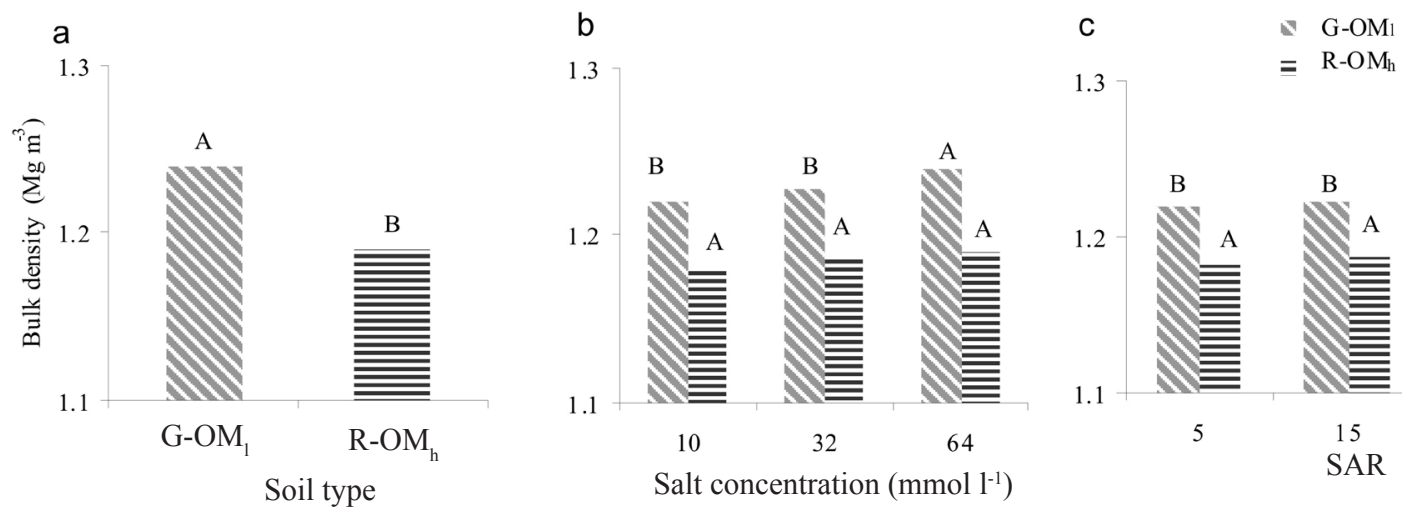

$\mathrm{R}-\mathrm{OM}$

Fig. 4. Bulk density as related: $\mathrm{a}$ - to the soil type (Udertic Ustochrept - G-OM $\mathrm{M}_{1}$ and Pachic Haploxeroll - R-OM $)$ ), b - salt concentration, and c - SAR of irrigation water after 2 years of reclamation. For each effect considered, the values followed by the same letter are not significantly different, according to the Duncan test at $\mathrm{p} \leq 0.01$.

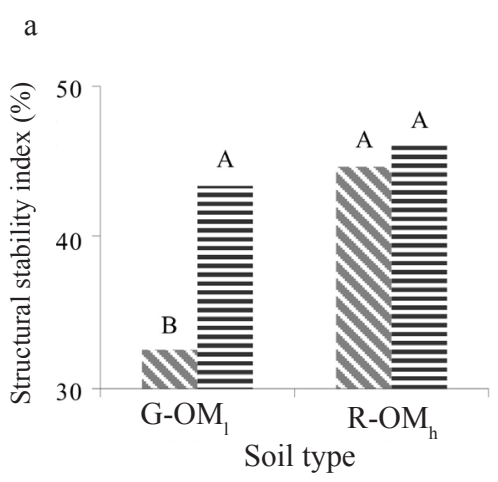

b

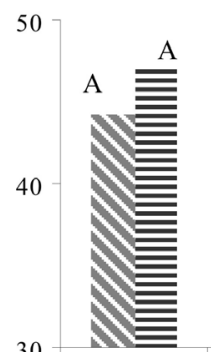

$\begin{array}{ccc}10 & 32 & 64 \\ \text { Salt concentration } & \left(\mathrm{mmol} \mathrm{l}^{-1}\right)\end{array}$

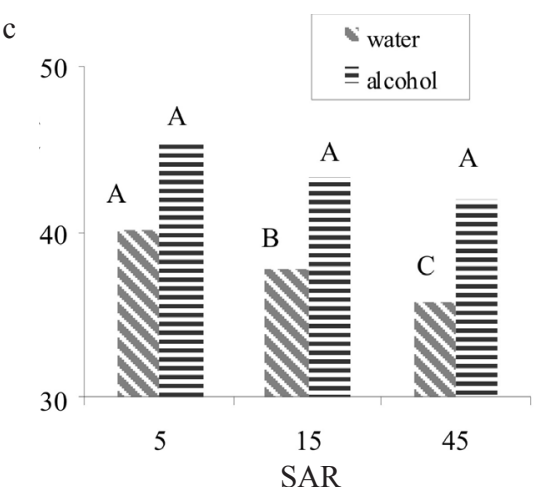

Fig. 5. Structural stability index with or without alcohol pretreatment as related: a - to the soil type (Udertic Ustochrept - G-OM and Pachic Haploxeroll - R-OM $), b$ - salt concentration, and c - SAR of irrigation water after 2 years of reclamation. For each effect considered, the values followed by the same letter are not significantly different, according to the Duncan test at $\mathrm{p} \leq 0.01$. 


\section{CONCLUSIONS}

1. In general, on two silty-clay textured soils, irrigation with sodic-saline water has not caused any permanent macroscopic effect of structure deterioration. After two years of reclamation both soils respectively showed values of bulk density very similar to those on the start of the experiment.

2. Nevertheless, the irrigation with sodic-saline water has caused in Udertic Ustochrep, which is structurally more unstable, harmful and more durable effects on the shape and size distribution of soil pores, as compared to Pachic Haploxeroll. For the soil Pachic Haploxeroll, characterized by a lower propensity to physical degradation, two years of soil conditioning treatments were sufficient to recover and nullify the effect of irrigation with sodic-saline water.

3. The structural stability index gradually decreased with the increasing salinization and sodification of the two soil types. In the red soil of Pachic Haploxeroll that is rich in illite and kaolin clay minerals, and well-supplied with organic matter and iron and aluminium sesquioxides, the structural aggregates have remained more stable.

\section{REFERENCES}

Abdelgawad A., Arslan A., Awad F., and Kadouri F., 2004. Deep plowing management practice for increasing yield and water use efficiency of vetch, cotton, wheat and intensified corn using saline and non-saline irrigation water. Proc. 55th IEC Meeting of the Int. Commission on Irrigation and Drainage (ICID), September 9-10, Moscow, Russia.

Ayers R.S. and Westcot D.W., 1985. Water quality for agriculture. Irrigation and Drainage Paper 29. Rev. 1. FAO, Rome. Italy.

Bian J.M., Liu C.H., and Yang Z.M., 2012. Influence of Planting Melilotus Offcinalia (MO) on Water and Salt in SalineAlkali Soil. J. Jilin Agric. Univ., 34, 176-179.

Blake G.R. and Hartge K.H., 1986. Bulk density. In: Methods of Soil Analysis (Ed. A. Klute). American Soc. Agronomy, Madison, WI, USA.

Bouma J., Jongerius A., Boersma O.H., JagerA., and Schoonderbeek D., 1977. The function of different types of macropores during saturated flow through four swelling soil horizons. Soil Sci. Soc. Am. J., 41, 945-950.

Cavazza L., Patruno A., and Cirillo E., 2002. Soil traits and structure stability in artificially sodicated soils. Italian J. Agron., 6(1), 15-25.

Chhabra R., 2005. Classification of Salt-Affected Soils. Arid Land Res. Manag., 19, 1, 61-79.

Cucci G. and Lacolla G., 2013. Irrigation with saline-sodic water: effects on two clay soils. Italian Journal of Agronomy, 8(13), 94-101.

Gal M., Arcan L., Shainberg I., and Keren R., 1984. Effect of exchangeable sodium and phosogypsum on crust structurescanning electron microscope observations. Soil Sci. Sec., Am. J., 48, 872-878.

Goldberg S. and Glaubig R.A., 1987. Effect of saturating cation, $\mathrm{pH}$ and aluminium and iron oxides on the flocculation of kaolinite and montmorillonite. Clays Clay Miner., 35, 220-227.
Greene R.S.B., Rengasamy P., Ford G.W., Chartres C.J., and Miller J.J., 1988. The effect of sodium and calcium on physical properties and micromorphology of two red-brown earth soils. J. Soil Sci., 39, 639-648.

Hénin S., Gras R., and Monnier G., 1969. Le profile cultural. Masson et Cie., Paris, France.

Ilyas M., Quresh, R.H., and Qadir M.A., 1997. Chemical changes in a saline-sodic soil after gypsum application and cropping. Soil Technol., 10, 247-260.

Kemper W.D. and Rosenau R.C., 1986. Aggregate stability and size distribution. In: Methods of Soil Analysis. Part. I. Physical and mineralogical methods (Ed. A. Klute). ASA and SSSA, Madison, WI, USA.

Ladeiro B., 2012. Saline Agriculture in the 21st Century: Using Salt Contaminated Resources to Cope Food Requirements. J. Botany, doi:10.1155/2012/310705

Miedema R., Pape T., and Van de Wall G.J., 1974. A method to impregnate wet soil samples, producing high quality thin sections. Neth. J. Agr. Sci., 22, 37-39.

Pagliai M., 1988. Soil porosity aspects. Int. Agrophysics, 4, 215-232.

Pagliai M., La Marca M., Lucamante G., and Genovese L., 1984. Effects of zero and conventional tillage on the length and irregularity of elongated pores in a clay loam soil under viticulture. Soil Till. Res., 4, 433-444.

Pagliai M., Torri D., and Patruno A., 1997. Stability and distribution dimensional aggregates. Physical methods of analysis soil (Ed. M. Pagliai), Franco Angeli Press, Roma, Italy.

Qadir M. and Oster J.D., 2004. Crop and irrigation management strategies for saline-sodic soils and waters aimed at environmentally sustainable agriculture. Sci. Total Environ., 323, 1-19.

Russo D., 2013. Consequences of salinity-induced-time-dependent soil hydraulic properties on flow and transport in saltaffected soils. Proc. Environ. Sci., 19: 623- 632.

Sakai Y., Ma Y., Xu C., Wu H., Zhu W., and Yang J., 2012. Phytodesalination of a salt-affected soil with four halophytes in China. J. Arid Land Studies, 22(1), 17 -20.

Saskatchewan Water Corporation, 1987. Irrigation Water Quality - Soil Compatibility: Guidelines for Irrigation in Saskatchewan. Saskatchewan Water Corporation, Canada.

Shainberg I. and Levy G.J., 1992. Physico-chemical effects of salts upon infiltration and water movemrnt in Soils. In: Interacting Processes in Soil Science (Eds R.S. Wagenet, P. Baveye, B.A. Stewart), Lewis Press, Boca Raton, FL, USA. Soil Survey Staff, 2006. Keys to Soil Taxonomy. 10th Edition. USDA Natural Res. Cons. Service, Washington, DC, USA.

U.S Salinity Laboratory Staff, 1954. Diagnosis and improvement of saline and alkali soils (Ed. L.A. Richards). U.S. Dept. Agriculture Handbook USDA, Washington, DC, USA.

Violante P., 2000. Chemical methods of soil analysis. Franco Angeli Press, Roma, Italy.

Zhang D.F. and Wang S.J., 2000. Mechanism of Freeze-thaw Action in Land Salinization Process As an sample in West Jilin Province. Bull. Soil and Water Conserv., 20, 14-17.

Zhao L.P., Feng J., Wang Y., Wang H.B., Geng Y.H., Wang S.H., and Li C.L., 2012. Theoretical and technological problems in the development of planting paddy in salinealkali land of Songnen. J. Jilin Agric. Univ., 34, 237-241. 